University of Nebraska - Lincoln

DigitalCommons@University of Nebraska - Lincoln

7-20-2009

\title{
Evaluating Chickpea Genotypes for Resistance to Ascochyta Blight in Nebraska
}

\author{
Robert M. Harveson \\ University of Nebraska-Lincoln, rharveson2@unl.edu \\ Carlos A. Urrea \\ University of Nebraska-Lincoln, currea2@unl.edu \\ David D. Baltensperger \\ Texas A\&M University, dbaltensperger@tamu.edu
}

Follow this and additional works at: https://digitalcommons.unl.edu/panhandleresext

Harveson, Robert M.; Urrea, Carlos A.; and Baltensperger, David D., "Evaluating Chickpea Genotypes for Resistance to Ascochyta Blight in Nebraska" (2009). Panhandle Research and Extension Center. 124. https://digitalcommons.unl.edu/panhandleresext/124

This Article is brought to you for free and open access by the Agricultural Research Division of IANR at DigitalCommons@University of Nebraska - Lincoln. It has been accepted for inclusion in Panhandle Research and Extension Center by an authorized administrator of DigitalCommons@University of Nebraska - Lincoln. 
(c) 2009 Plant Management Network.

Accepted for publication 11 May 2009. Published 20 July 2009.

\title{
Evaluating Chickpea Genotypes for Resistance to Ascochyta Blight in Nebraska
}

Robert M. Harveson and Carlos A. Urrea, Panhandle Research and Extension Center, University of Nebraska, Scottsbluff, NE 69361; and David D. Baltensperger, Department of Soil and Crop Sciences, Texas A\&M University, College Station, TX 77843

Corresponding author: Robert M. Harveson. rharveso@unlnotes.unl.edu

Harveson, R. M., Urrea, C. A., and Baltensperger, D. D. 2009. Evaluating chickpea genotypes for resistance to ascochyta blight in Nebraska. Online. Plant Health Progress doi: 10.1094/PHP-2009-0720-01-RS.

\begin{abstract}
Ten irrigated or dryland chickpea field trials in the Nebraska Panhandle over the three year period (2005-2007) assessed parental genotypes and cultivars for disease resistance to Ascochyta blight caused by Aschochyta rabiei. The most promising genotypes for all aspects of disease resistance were the breeding lines PI 17256 and CA0090B347C. PI 17256 had significantly better disease ratings in two of the four dryland trials and five of the six irrigated trials compared to the three standard commercial cultivars (Dylan, Dwelley, and Sierra). Overall, breeding line CA0090B347C was intermediate between PI 17256 and the other entries in terms of disease resistance, with similar ratings to PI 17256 but better than the commercial cultivars in two of the four dryland trials and two of the six irrigated trials. PI 17256 produced the highest yields in three trials, while CA0090347C produced significantly higher yields than the commercial cultivars in three other trials. These two lines should be useful as germplasm sources for ongoing breeding efforts to develop new, adapted blight-tolerant cultivars for Nebraska.
\end{abstract}

\section{I ntroduction}

Interest in chickpea (Cicer arietinum L.), also known as the garbanzo bean, as an alternative crop to spring cereals has been on the increase in areas of the United States where rainfall is marginal (9). The leading producing states are Idaho, Washington, California, and North Dakota. Chickpea production began to substantially increase in Nebraska from 1998-2000, due in part to this crop's ability to fit well within existing production systems in this area as a rotational crop. Acreage increased from 1,500 acres in 2000 to almost 10,000 acres in 2001 and 2006 and continued production increases are expected.

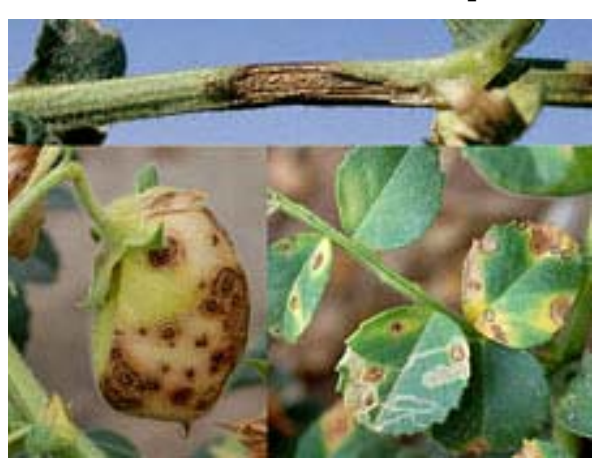

Fig. 1. Ascochyta blight symptoms on chickpea: elongate lesions on stem (top), and circular lesions on leaves (bottom right) and pods (bottom left).

$(1,11)$. The pathogen attacks all aerial portions of the plant (Fig. 1), and causes economic losses due to reduced yields as well as reduced quality (Fig. 2) $(5,10)$. For a crop like chickpeas, quality may be more important than gross yields, as payments for small discolored seeds 
(result of pod and seed infection) are significantly lowered. Seed infections can be either internal or external on the seed surface, and both types of infections are equally capable of transmitting the pathogen to emerging seedlings $(1,11)$. Infected seeds serve as a major mechanism for pathogen survival, long distance movement, and initiation of new infections (5). The pathogen may also overwinter in crop residues for several years, and be disseminated in spring to other fields via wind-blown spores (10). Early in the season, infected seedlings are found scattered in fields $(4,5,10)$. These plants are sources of inocula for secondary spread during periods of conducive environmental conditions.

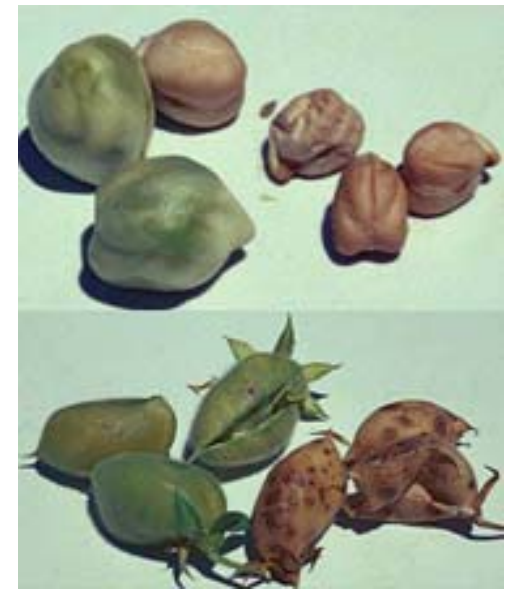

Fig. 2. Effect of Ascochyta rabiei infection on chickpea seed size: seeds (top) harvested from pods (bottom) collected from the severely infested field, healthy (left) and infected (right).

Currently, there are few viable management options for Nebraska producers. Fungicide seed treatments have been shown to improve initial stands, but do not protect from disease that develops later in the season from the infected seeds (8). Because of the small profit margins for chickpeas in Nebraska, growers have additionally been reluctant to make multiple fungicide applications for blight control, which is often needed for profitable crop yields. Therefore, unless new cultivars with adequate levels of resistance are identified and implemented by growers, chickpea production in Nebraska will not likely continue.

\section{Resistance to Ascochyta Blight}

Developing new resistant cultivars will additionally be a challenging task as numerous conflicting reports concerning the genetics of Ascochyta blight resistance have been made by researchers working with this disease. Tewari and Pandey (13) found that resistance was controlled by three independently segregating genes in three distinct genotypes. Dey and Singh (3) determined that resistance to blight in two separate lines is governed by two dominant genes, whereas resistance in a black seeded line was controlled by one dominant and one recessive independent gene. Vir et. al (14) found that blight resistance in one line was controlled by a single dominant gene pair. Other studies have concluded that resistance found in cultivars is partial and incomplete $(2,12)$.

Identification of genotypes with improved resistance to the disease is critical to rapid development of new blight resistant cultivars and the future of this crop in Nebraska, and other areas of the Central High Plains. The objective was to assess Ascochyta blight reaction and yield for selected chickpea parental genotypes and cultivars.

\section{Multi-Site Field Trials}

Ten trials were conducted in the Nebraska Panhandle from 2005 to 2007. These included four dryland trials (Scottsbluff 2006; Sidney 2006; and Alliance 2005 and 2006), and six irrigated trials (Scottsbluff 2005, 2006, and 2007; Sidney 2006; and Alliance 2005 and 2006]. The Alliance trials were conducted on a grower's farm, while the other six were conducted on experiment farms affiliated with the University of Nebraska, including the Panhandle Research 
and Extension Center, Scottsbluff, and High Plains Agricultural Laboratory, Sidney, NE.

Each trial included 14 entries (genotypes), but for this report we chose to present the 9 genotypes common to all trials over the 3 year period (Table 1). Genotypes consisted of six advanced breeding lines and three commercial cultivars, all of which were obtained from the chickpea breeding program at Washington State University. All genotypes in these trials were the large-seeded Kabuli type, but leaf type varied from the single unifoliate to the compound "fern leaf" type. Chickpea market types "Kabuli" or the smaller "desi" are based on seed size, shape, and color.

Table 1. Chickpea genotypes common to ten Nebraska field trials evaluating Ascochyta blight resistance (2005 to 2007).

\begin{tabular}{|c|c|c|}
\hline Genotype & Leaf type & Source $^{x}$ \\
\hline Dwelley & Unifoliate & Commercial cultivar \\
\hline Dylan & Compound & Commercial cultivar \\
\hline Sierra & Unifoliate & Commercial cultivar \\
\hline CA9783163C & Compound & Washington State University \\
\hline CA9990B1579C & Unifoliate & Washington State University \\
\hline CA0090B347C & Unifoliate & Washington State University \\
\hline CA9890233W & Compound & Washington State University \\
\hline Troy & Compound & Washington State University \\
\hline PI 17256 & Compound & USDA Plant Introduction, Pullman, WA \\
\hline
\end{tabular}

$x$ All entries provided by Western Regional PI Station, Pullman, WA

Genotypes were assigned to experimental units (plots) using a randomized complete block design with four replications for each trial. All plots were eight rows spaced $1.7 \mathrm{~m}$ wide. Plot lengths varied by location (Alliance $6 \mathrm{~m}$; Scottsbluff irrigated $3 \mathrm{~m}$ and dryland $6 \mathrm{~m}$; and Sidney irrigated $7.4 \mathrm{~m}$ and dryland $10 \mathrm{~m}$ ). Starter fertilizer (11-51-0) was broadcast applied preplant to the irrigated tests to achieve $11 \mathrm{~kg} /$ ha $\mathrm{P}_{2} \mathrm{O}_{5}$. Sulfentrazone (FMC Corp., Philadelphia, PA) was applied preplant to the soil surface at $280 \mathrm{~g}$ ai/ ha for broadleaf weed control and $72 \mathrm{~g}$ ai/ ha of quizalofop (Dupont, Wilmington, DE) was used post-plant for grass weed control. All tests were planted in late April to achieve a final population of three to four plants/ $\mathrm{ft}^{2}$ and harvested in late August or early September with a Wintersteiger plot combine (Wintersteiger Inc., Salt Lake City, UT). Yield parameters were assessed on individual samples in the lab.

Blight ratings in mid-J uly used a 1 to 5 scale where $1=100 \%$ stand and no disease, $2=75 \%$ stand and $<25 \%$ of plants showing symptoms, $3=50 \%$ stand and $50 \%$ of plants showing symptoms, $4=25 \%$ stand and up to $75 \%$ of plant showing symptoms, and $5=$ no stand or $>75 \%$ of plant showing symptoms (Tables 2 and 3). This scale takes into account the estimated disease incidence within plots, but also includes estimated plant stands. Ascochyta blight can readily affect final established stands if unprotected seeds are severely infected (Figs. 3 and 4). 
Table 2. Ascochyta blight ratings ( 1 to 5 scale, 1 for no disease) for six chickpea irrigated trials in Nebraska (2005 to 2007).

\begin{tabular}{|l|c|c|c|c|}
\hline Genotype & $\begin{array}{c}\text { Scottsbluff } \\
\mathbf{2 0 0 5 - 2 0 0 7}\end{array}$ & $\begin{array}{c}\text { Sidney } \\
\mathbf{2 0 0 6}\end{array}$ & $\begin{array}{c}\text { Alliance } \\
\mathbf{2 0 0 5}\end{array}$ & $\begin{array}{c}\text { Alliance } \\
\mathbf{2 0 0 6}\end{array}$ \\
\hline Dwelley & $2.8 \mathrm{a}^{\mathrm{y}}$ & $3.9 \mathrm{~b}$ & $1.5 \mathrm{bc}$ & $2.8 \mathrm{a}$ \\
\hline Dylan & $3.0 \mathrm{a}$ & $4.9 \mathrm{a}$ & $2.3 \mathrm{a}$ & $2.0 \mathrm{~cd}$ \\
\hline Sierra & $2.8 \mathrm{a}$ & $3.4 \mathrm{bc}$ & $2.1 \mathrm{ab}$ & $2.4 \mathrm{ab}$ \\
\hline CA9783163C & $3.2 \mathrm{a}$ & $3.4 \mathrm{~b}$ & $1.1 \mathrm{c}$ & $2.0 \mathrm{~cd}$ \\
\hline CA9990B1579C & $2.9 \mathrm{a}$ & $2.6 \mathrm{~cd}$ & $2.3 \mathrm{a}$ & $2.4 \mathrm{ab}$ \\
\hline CA0090B347C & $2.7 \mathrm{a}$ & $2.4 \mathrm{de}$ & $2.4 \mathrm{a}$ & $1.9 \mathrm{~d}$ \\
\hline CA9890233W & $2.8 \mathrm{a}$ & $3.3 \mathrm{bc}$ & $1.8 \mathrm{abc}$ & $2.3 \mathrm{bc}$ \\
\hline Troy & $2.8 \mathrm{a}$ & $3.4 \mathrm{~b}$ & $1.8 \mathrm{abc}$ & $1.8 \mathrm{de}$ \\
\hline PI 17256 & $1.6 \mathrm{~b}$ & $1.5 \mathrm{e}$ & $2.3 \mathrm{a}$ & $1.5 \mathrm{e}$ \\
\hline Mean & 2.7 & 3.2 & 1.9 & 2.1 \\
\hline
\end{tabular}

$x$ Data for 3 Scottsbluff trials were combined for analysis due to no trial $x$ genotype interactions.

y LSD mean separations are based on the PROC RANK transformed rankings.

Table 3. Ascochyta blight ratings ( 1 to 5 scale, 1 for no disease) for four dryland chickpea trials in Nebraska (2005-2006).

\begin{tabular}{|l|c|c|c|c|}
\hline Genotype & $\begin{array}{c}\text { Scottsbluff } \\
\mathbf{2 0 0 6}\end{array}$ & $\begin{array}{c}\text { Sidney } \\
\mathbf{2 0 0 6}\end{array}$ & $\begin{array}{c}\text { Alliance } \\
\mathbf{2 0 0 5}\end{array}$ & $\begin{array}{c}\text { Alliance } \\
\mathbf{2 0 0 6}\end{array}$ \\
\hline Dwelley & $1.8 \mathrm{bc}^{\mathrm{x}}$ & $3.0 \mathrm{ab}$ & $1.8 \mathrm{c}$ & $2.8 \mathrm{ab}$ \\
\hline Dylan & $1.9 \mathrm{ab}$ & $3.3 \mathrm{a}$ & $2.6 \mathrm{a}$ & $2.4 \mathrm{bc}$ \\
\hline Sierra & $1.9 \mathrm{ab}$ & $2.5 \mathrm{bc}$ & $2.3 \mathrm{ab}$ & $3.0 \mathrm{a}$ \\
\hline CA9783163C & $1.5 \mathrm{c}$ & $2.5 \mathrm{bc}$ & $2.5 \mathrm{bc}$ & $2.1 \mathrm{~cd}$ \\
\hline CA9990B1579C & $2.3 \mathrm{a}$ & $2.4 \mathrm{bcd}$ & $2.0 \mathrm{abc}$ & $2.8 \mathrm{ab}$ \\
\hline CA0090B347C & $2.0 \mathrm{ab}$ & $2.0 \mathrm{de}$ & $2.4 \mathrm{ab}$ & $2.0 \mathrm{de}$ \\
\hline CA9890233W & $1.5 \mathrm{c}$ & $2.4 \mathrm{~cd}$ & $2.1 \mathrm{abc}$ & $2.1 \mathrm{~cd}$ \\
\hline Troy & $1.5 \mathrm{c}$ & $2.5 \mathrm{c}$ & $2.1 \mathrm{abc}$ & $2.0 \mathrm{de}$ \\
\hline PI 17256 & $1.5 \mathrm{c}$ & $1.5 \mathrm{e}$ & $2.5 \mathrm{ab}$ & $1.6 \mathrm{e}$ \\
\hline Mean & 1.8 & 2.4 & 2.2 & 2.3 \\
\hline
\end{tabular}

$x$ LSD mean separations are based on the PROC RANK transformed rankings.

Table 4. Chickpea yields from six irrigated trials in Nebraska (2005-2007).

\begin{tabular}{|l|c|c|c|c|c|c|}
\hline \multirow{2}{*}{ Genotype } & \multicolumn{7}{|c|}{ Yield (kg/ha) } \\
\cline { 2 - 7 } & $\begin{array}{c}\text { Scottsbluff } \\
2005\end{array}$ & $\begin{array}{c}\text { Scottsbluff } \\
2006\end{array}$ & $\begin{array}{c}\text { Scottsbluff } \\
2007\end{array}$ & $\begin{array}{c}\text { Sidney } \\
2006\end{array}$ & $\begin{array}{c}\text { Alliance } \\
2005\end{array}$ & $\begin{array}{c}\text { Alliance } \\
2006\end{array}$ \\
\hline Dwelley & 851 & 2190 & 138 & 71 & 1704 & 1387 \\
\hline Dylan & 871 & 2319 & 188 & 18 & 1348 & 1403 \\
\hline Sierra & 1509 & 2354 & 358 & 215 & 1526 & 1738 \\
\hline CA9783163C & 716 & 2134 & 104 & 41 & 1579 & 1471 \\
\hline CA9990B1579C & 1645 & 2332 & 69 & 390 & 1721 & 1503 \\
\hline CA0090B347C & 1954 & 2289 & 327 & 874 & 2105 & 1795 \\
\hline CA9890233W & 484 & 2445 & 126 & 138 & 1330 & 1523 \\
\hline Troy & 329 & 2134 & 261 & 44 & 1140 & 1236 \\
\hline PI 17256 & 1661 & 1048 & 341 & 1456 & 1846 & 1574 \\
\hline Mean & 1097 & 2138 & 213 & 360 & 1576 & 1514 \\
\hline LSD (0.05) & 366 & 380 & 103 & 198 & 352 & 352 \\
\hline \hline
\end{tabular}




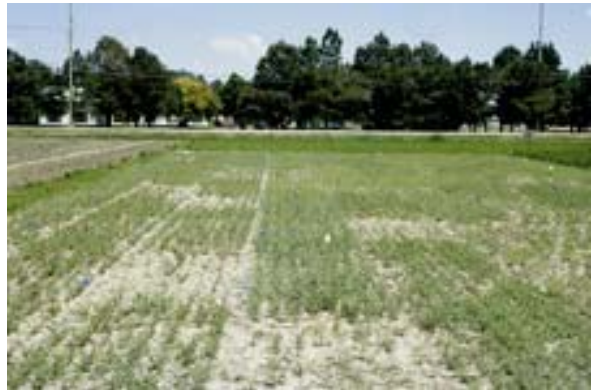

Fig. 3. Effect of seedborne Ascochyta rabiei on early chickpea stand establishment. Note the poor stands in those plots planted with seeds without fungicide seed treatments.

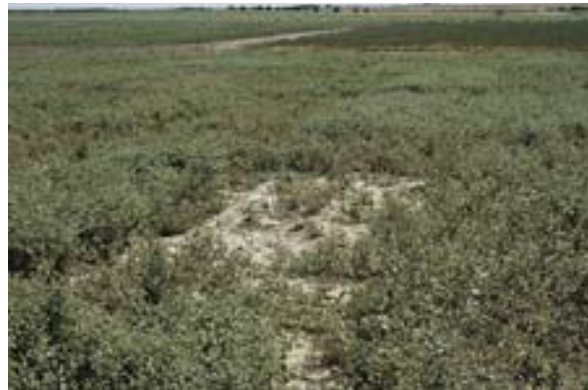

Fig. 4. Chickpea plots ready for harvest. Plot with severe Ascochyta blight disease (center) was planted using a susceptible genotype without fungicide seed treatment.

\section{Data Analysis}

The disease rating variances for the three irrigated Scottsbluff sites (2005 to 2007) were homogeneous and no trial $\times$ genotype interactions were observed. Therefore, the data were pooled for analysis for these three sites only (Table 2). All other disease ratings and yield data are presented separately by year and location, due to trial $\times$ genotype interactions (Tables 2 to 5). Because the disease ratings were based on an ordinal scale, the data were transformed using PROC RANK before performing an analysis of variance using PROC GLM (SAS Institute Inc., Cary, NC). Differences among the ranked entries were then separated by LSD tests at $\mathrm{P}<0.05$. Yield analyses for all trials utilized the GLM procedure, and means were also separated by LSD $(\mathrm{P}<0.05)$. Correlation analyses were additionally performed comparing the disease ratings with the yield results from each trial.

Table 5. Chickpea yields from four dryland trials in Nebraska (2005-2006).

\begin{tabular}{|l|c|c|c|c|}
\hline \multirow{2}{*}{ Genotype } & \multicolumn{4}{|c|}{ Yield (kg/ha) } \\
\cline { 2 - 5 } & $\begin{array}{c}\text { Scottsbluff } \\
\mathbf{2 0 0 6}\end{array}$ & $\begin{array}{c}\text { Sidney } \\
\mathbf{2 0 0 6}\end{array}$ & $\begin{array}{c}\text { Alliance } \\
\mathbf{2 0 0 5}\end{array}$ & $\begin{array}{c}\text { Alliance } \\
\mathbf{2 0 0 6}\end{array}$ \\
\hline Dwelley & 63 & 525 & 1160 & 130 \\
\hline Dylan & 105 & 361 & 1049 & 272 \\
\hline Sierra & 172 & 686 & 1240 & 216 \\
\hline CA9783163C & 14 & 521 & 1425 & 198 \\
\hline CA9990B1579C & 297 & 745 & 1255 & 265 \\
\hline CA0090B347C & 157 & 845 & 1681 & 285 \\
\hline CA9890233W & 77 & 584 & 1268 & 250 \\
\hline Troy & 61 & 441 & 1123 & 147 \\
\hline PI 17256 & 336 & 936 & 1228 & 332 \\
\hline Mean & 142 & 627 & 1270 & 233 \\
\hline LSD (0.05) & 138 & 172 & 256 & 140 \\
\hline
\end{tabular}

\section{Entry Performance}

The incidence and severity of blight varied considerably among the trials. The average severity ratings for all entries ranged from 1.8 at the Scottsbluff dryland trial in 2006 to 3.2 at the Sidney irrigated trial in 2006 (Tables 2 and 3). Overall, the irrigated trials resulted in slightly higher ratings (average of 2.5) compared to the dryland trials (average of 2.2). Yield results likewise varied widely and ranged from a low of $142 \mathrm{~kg} / \mathrm{ha}$ at the dryland Scottsbluff trial in 2006 to a high of $2138 \mathrm{~kg} / \mathrm{ha}$ at the Scottsbluff irrigated site in 2006 (Tables 4 and 5). Average yields across all entries were higher from the six irrigated trials (1150 kg/ ha) than from the four dryland trials (568 kg/ ha) (Tables 4 and 5). Eight of the ten trials resulted in inverse relationships between blight ratings and yield, with five of these being statistically significant (Table 6). Two genotypes showed promise for resisting disease and yielding adequately under 
western Nebraska conditions, including PI 17256 and CA0090B347C. The PI 17256 line consistently demonstrated the greatest degree of resistance to the pathogen, regardless of the type of production. It produced significantly better disease ratings in two of the four dryland trials (Sidney 2006, and Alliance 2006) and five of the six irrigated trials compared to the three standard commercial cultivars (Dylan, Dwelley, and Sierra) (Tables 2 and 3). The breeding line CA0090B347C was intermediate between PI 17256 and the other entries in terms of disease resistance. It produced ratings that were similar but statistically insignificant from PI 17256 but better than the commercial cultivars in two of the four dryland trials and two of the six irrigated trials.

Table 6. Correlations between Ascochyta blight ratings and chickpea yields for irrigated and dryland trials in Nebraska.

\begin{tabular}{|l|c|c|}
\hline & I rrigated & Dryland \\
\hline Scottsbluff 2005 & $-0.38^{\mathrm{x}}$ & - \\
\hline Scottsbluff 2006 & $-0.63^{\mathrm{x}}$ & -0.21 \\
\hline Scottsbluff 2007 & $-0.41^{\mathrm{y}}$ & - \\
\hline Sidney 2006 & $-0.79^{\mathrm{X}}$ & $-0.74^{\mathrm{x}}$ \\
\hline Alliance 2005 & -0.02 & -0.13 \\
\hline Alliance 2006 & -0.13 & -0.32 \\
\hline
\end{tabular}

$x$ Significant relationship $(P<0.01)$.

y Significant relationship $(P<0.05)$.

Yield results also illustrate the potential benefits of these two breeding lines. At least one of the two lines resulted in significantly higher yields compared to the three commercial cultivars in six of the ten trials. PI 17256 produced the highest yields in three trials (2006 Sidney irrigated, 2006 Sidney dryland, and 2007 Scottsbluff dryland), while CA0090347C produced significantly higher yields than the commercial cultivars in three other trials (2005 Scottsbluff irrigated, 2005 Alliance dryland, and 2005 Alliance irrigated (Tables 4 and 5).

The commercial cultivar Sierra did not exhibit the same high levels of resistance that PI 17256 did. However, it yielded similarly to PI 17256 and/or CA0090347C in four trials, including 2006 and 2007 Scottsbluff irrigated, 2006 Alliance irrigated and 2006 Alliance dryland (Tables 4 and 5).

\section{Conclusions}

Chickpeas have several advantages that make them an attractive alternative crop for producers in western Nebraska. They fit well with existing equipment, dry bean processors and regional infrastructure. Furthermore they serve as an excellent rotational crop that can fit into either dryland or irrigated cropping systems in Nebraska. This would be particularly valuable in the dryland areas dominated by grass crops (winter wheat and proso millet).

Previous research from Nebraska has indicated that a great deal of variability exists in some economically important traits within potential cultivars, including yield, seed size, quality, and disease resistance $(6,7,8)$. Identifying disease resistant genotypes with acceptable yield and quality will help this region (Colorado, Nebraska, and Wyoming) become a more competitive production area.

Of those genotypes tested, the most promising for all aspects of disease resistance and production were breeding lines PI 17256 and CA0090B347C. Although both are Kabuli-types, seed sizes were smaller than the commercial standard. PI 17256 exhibits better disease resistance than CA0090347C, but produces smaller seed. Nevertheless, these two lines should still be useful as parental germplasm sources for ongoing breeding efforts to develop new blightresistant cultivars with the desired agronomic traits for Nebraska and other areas of the Central High Plains. In the meantime, we have also determined that the cultivar Sierra may be an acceptable alternative for many producers until 
more resistant high yielding cultivars are developed, but its use would likely have to be integrated with both fungicide seed treatments and foliar applications for disease management.

Evaluation of more genotypes for resistance and developing new cultivars will remain a priority in the hope of stimulating more interest in irrigated and dryland chickpea production. Both dryland and irrigated trials are necessary for Ascochyta blight evaluations because substantial disease and yield variations were observed among trials. Because the pathogen is almost always seedborne to some extent, inoculations were not required to initiate disease. For future germplasm evaluations for disease resistance, we will continue to omit seed treatment fungicides but rotate with unrelated crops for at least 3 years. Estimating yield is useful for evaluating genotype response to the pathogen, since it was correlated with disease severity ratings from the majority of the trials.

\section{Literature Cited}

1. Allen, D. J. 1983. The Pathology of Tropical Food Legumes, Disease Resistance in Crop Improvement. J ohn Wiley and Sons, New York, NY.

2. Danehloueipour, N., Yan, G., Clarke, H. J ., and Sialdique, K. H. M. 2007. Diallel analysis reveals the genetic control of resistance to Ascochyta blight in diverse chickpea and wild Cicer species. Euphytica 154:195-205.

3. Dey, S. K., and Singh, G. 1993. Resistance to Ascochyta blight in chickpeas. Euphytica 68:147-153.

4. Harveson, R. M. 2002. A severe outbreak of Ascochyta blight of chickpeas in western Nebraska. Plant Dis. 86:698.

5. Harveson, R. M. 2007. Ascochyta Blight of Chickpeas in Nebraska. Coop. Ext. NebGuide G1676. Univ. of Nebraska, Lincoln, NE.

6. Harveson, R. M., and Baltensperger, D. D. 2005. Evaluating chickpea lines for disease resistance in western Nebraska. (Abstr.) Phytopathology 95:S40.

7. Harveson, R. M., and Baltensperger, D. D. 2005. Response of chickpea lines to natural infections of Ascochyta blight in western Nebraska, 2004. Biol. Cult. Tests 20:FC007.

8. Harveson, R. M., Urrea, C. A., and Baltensperger, D. D. 2006. Evaluating fungicide seed treatments for season-long control of Ascochyta blight on chickpeas in Nebraska, 2005. Fung. Nem. Tests 61:ST027.

9. Margheim, J. F., Baltensperger, D. D., Wilson, R. G., Lyon, J. L., Hein, G. L., Harveson, R. M., Burgener, P. A., Krall, J . M., Cecil, J. T., Rickertsen, J. R., Merrigan, A. P., Watson, M. H., and Hansen, B. J . 2004. Chickpea production in the High Plains. Coop. Ext. EC04-183. Univ. of Nebraska, Lincoln, NE.

10. Markell, S., Wise, K., McKay, K., Goswami, R., and Gudmestad, N. 2008. Ascochyta Blight of Chickpea. Coop. Ext. Serv. Publ. PP-1362. North Dakota State Univ., Fargo, ND.

11. Nene, Y. L., and Reddy, M. V. 1987. Chickpea diseases and their control. Pages 233270 in: The Chickpea. M. C. Saxena and K. B., Singh, eds. CAB Intl., Wallinford, UK.

12. Smith, L. J . 2005. North Central Idaho on-farm-fungicide evaluation for Ascochyta Blight in chickpeas. (Abstr). Phytopathology 97:S171

13. Tewari, S. K., and Pandey, M. P. 1986. Genetics of resistance to Ascochyta blight in chickpeas (Cicer arietinum L.). Euphytica 35:211-215.

14. Vir, S., Grewal, J. S., and Gupta, V. P. 1975. Inheritance of resistance to Ascochyta blight in chickpeas. Euphytica 24:209-211. 